warheads, and have them transfer their skills to a new generation," says Harvey. Maintaining these skills will allow the United States to respond to future threats, he adds.

But Chris Paine, an analyst at the Natural Resources Defense Council, an environmental group that keeps a close track of the US weapons programme, says that such skills are unnecessary. "This is no longer a growth industry," he says. Paine predicts that the design effort will serve to undermine non-proliferation, and encourage other countries to develop nuclear weapons of their own.

Richard Garwin, a physicist and former head of research at IBM who has advised successive US governments on nuclear-weapons policy, suggests that the design activity may ultimately lead to a resumption of nuclear testing, which the United States abandoned in 1992.

But Harvey maintains that most of the activity would be restricted to computer simulation and testing of weapon components. "Our intention would be to carry out new development consistent with the president's moratorium on testing," he says. But he concedes that the possibility of future tests remains "an open question".

\title{
Power vacuum expands as CDC director resigns
}

\section{Meredith Wadman, Washington}

Four of the main health administration jobs in the US government are now vacant, following Jeffrey Koplan's resignation as director of the Centers for Disease Control and Prevention (CDC) on 21 February.

As well as the CDC, the National Institutes of Health (NIH) and the Food and Drug Administration are without permanent directors. The figurehead position of surgeon general - who offers health advice to the US public — fell vacant a few weeks ago with the departure of David Satcher.

The vacancies are a source of mounting concern to health advocates, who say that the situation will take its toll on biomedical research and public health. "It's just a glaring gap in scientific leadership at a critical time," says Tony Mazzaschi, associate vicepresident for research at the Association of American Medical Colleges.

But Bill Hall, a spokesman for health secretary Tommy Thompson, says: "We have very, very competent people who are acting in those positions right now and who are doing a fantastic job."

Nevertheless, the NIH has been without a permanent director for more than two years. And in the past week Anthony Fauci, director of the National Institute of Allergy and Infectious Diseases (NIAID), has fallen out of the running for the NIH's top job. White House officials say this was because he wanted to maintain his job at the NIAID while serving as NIH director - but others contend that conservatives spiked his nomination because of his past support for fetal-tissue research.

Elias Zerhouni, a radiologist and senior administrator at Johns Hopkins University School of Medicine in Baltimore, Maryland, is now being floated as a contender for the post. But he inspired a new centre at Johns Hopkins that conducts embryonic stem-cell research, and looks as vulnerable as anyone to the political machinations that are holding up health-related appointments.

\section{Minimum standards set out for gene-expression data}

\section{Jonathan Knight, Boston}

A grassroots collection of biologists plans to persuade scientific journals to enforce minimum standards for the publication of all experiments involving microarrays.

The arrays, which monitor the expression of thousands of genes simultaneously, have proved to be helpful in the discovery of genes that influence such diverse processes as cancer and embryonic development. But whereas DNA sequences are always in the same format, microarray

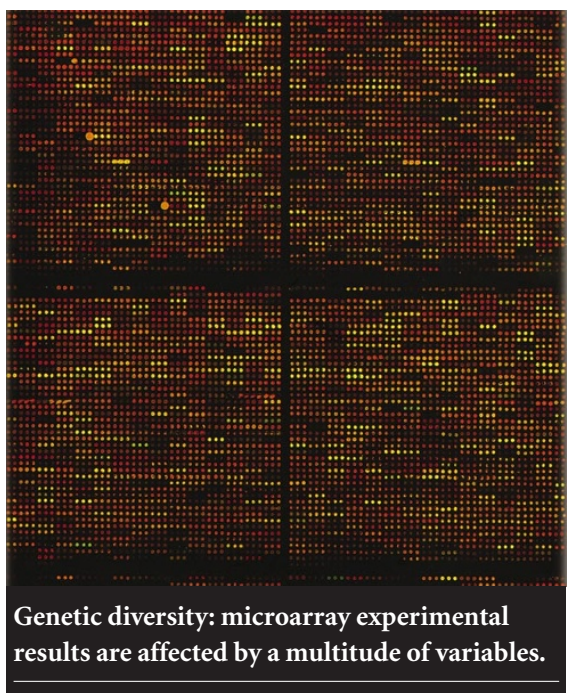

experiments are difficult to compare with one another, because of the multitude of variables that affect their outputs (see Nature 410, 851, 860-861; 2001).

In an effort to remedy this, the Microarray Gene Expression Database (MGED) Group first devised a common set of standards - called minimum information about a microarray experiment (MIAME) - in 1999.

But although many papers now refer to the MIAME standards, compliance is uneven, says Catherine Ball, curator of the Stanford Microarray Database. "At the moment, it's terrible," she says. "I often find I can't identify genes or that people have used home-grown software they don't describe."

"Generally, we want the same thing you have with published DNA sequences," says Alvis Brazma, head of microarray informatics at the European Bioinformatics Institute in Cambridge, UK. This means that all primary research data should be submitted to a repository, he says. The standards would also require the publication of enough experimental detail to allow other scientists to compare different data sets.

In early March, the MGED steering committee, of which Ball and Brazma are members, plans to release a check-list based on MIAME for use by authors, editors and referees. The list will be designed to make it easy for journals to request, and ultimately require, MIAME compliance.

The final check-list is likely to ask for details of sample preparation and data processing, as well as numerical read-outs of the intensity of the array's red and green spots, which indicate the level of gene expression.

Ball says that the check-list won't require authors to reveal every gene on an array, as this could allow others to scoop experiments in progress. "No one would argue that you should publish data prematurely," she says. "You can strip out the gene identity of things you are not publishing."

Journal editors are enthusiastic about the proposed check-list, but say that they will consult the microarray researchers before requiring authors to comply with it. "We'd consider insisting if the community showed broad consensus," says Nature's editor, Philip Campbell.

Laurie Goodman, executive editor of Genome Research, published by Cold Spring Harbor Laboratory, says that she would be cautious about requirements that could rule out important papers, but would consider adopting minimum standards if she received a strong indication that microarray users support them. nww.mged.org 